\title{
Animal health problems caused by silicon and other mineral imbalances
}

\author{
HENRY F. MAYLAND AND GLENN E. SHEWMAKER
}

Authors are research soil scientist, Northwest Irrigation and Soils Research Laboratory, USDA-ARS, 3793N 3600E, Kimberly, Ida 83341-5076; and extension forage specialist, University of Idaho, Twin Falls, Ida 83303-1827. e-mail <mayland@ kimberly.ars.pn.usbr.gov>

\begin{abstract}
Plant growth depends upon $\mathrm{C}, \mathrm{H}, \mathrm{O}$, and at least 13 mineral elements. Six of these ( $\mathrm{N}, \mathrm{K}, \mathrm{Ca}, \mathrm{Mg}, \mathrm{P}$, and $\mathrm{S}$ ) macro-elements normally occur in plants at concentrations greater than $1,000 \mathrm{mg}$ $\mathrm{kg}^{-1}$ level. The remaining micro-elements $(\mathrm{B}, \mathrm{Cl}, \mathrm{Cu}, \mathrm{Fe}, \mathrm{Mn}, \mathrm{Mo}$, and $\mathrm{Zn}$ ) normally occur in plants at concentrations less than 50 $\mathrm{mg} \mathrm{kg}^{-1}$. Trace amounts of other elements (e.g., Co, Na, Ni, and $\mathrm{Si}$ ) may be beneficial for plants. Silicon concentrations may range upwards to $50,000 \mathrm{mg} \mathrm{kg}^{-1}$ in some forage grasses. Mineral elements required by animals include the macro-elements $\mathrm{Ca}, \mathrm{Cl}$, $\mathrm{K}, \mathrm{Mg}, \mathrm{N}, \mathrm{Na}, \mathrm{P}$, and $\mathrm{S}$; the trace or micro-elements $\mathrm{Co}, \mathrm{Cu}, \mathrm{Fe}$, $\mathrm{I}, \mathrm{Mn}, \mathrm{Mo}$, Se, and $\mathrm{Zn}$; and the ultra-trace elements $\mathrm{Cr}$, Li, and $\mathrm{Ni}$. When concentrations of these elements in forages get 'out of whack' their bioavailability to animals may be jeopardized. Interactions of $\mathrm{K} \times \mathrm{Mg} \times \mathrm{Ca}$, Ca $\times \mathrm{P}$, Se $\times \mathrm{S}$, and $\mathrm{Cu} \times \mathrm{Mo} \times \mathrm{S}$ are briefly mentioned here because more detail will be found in the literature. Limited published information is available on $\mathrm{Si}$, so we have provided more detail. Silicon provides physical support to plants and may reduce susceptibility to pests. However, Si may have negative effects on digestibility and contribute to urinary calculi in animals.
\end{abstract}

Key Words: Forage, mineral interaction, mineral requirements, mineral nutrition, ruminant diets.

Simple deficiency or excess of dietary mineral elements may cause animal health concerns. In addition there are known imbalances among elements that directly or indirectly affect bioavailability of other elements (Grace and Clark 1991, Grace 1994). Through out the review, reference will be made to ruminant mineral requirements as given in Table 1 . Nearly all mineral elements, whether essential or nonessential, can adversely affect an animal if included in the diet at excessively high levels (Gough et al. 1979, NRC 1980). Forage, concentrates, mineral supplements, and drinking water serve as sources of consumed mineral elements. Soil ingestion provides yet another source of soluble or extractable mineral elements (Mayland et al. 1975). The connection between minerals in the diet and health of animals has been previously covered by others, including Harris et al. 1989, Kabata-Pendias and Pendias 1992, Mayland and Cheeke 1995, Nicholas and Egan 1975, Reid and Horvath 1980, Spears 1994. This paper will generally overlook simple cases of deficiency or toxicity. Instead it emphasizes mineral interactions leading to mineral imbalances

Manuscript accepted 27 Nov. 00.

\section{Resumen}

El crecimiento vegetal depende del $\mathrm{C}, \mathrm{H}, \mathrm{O}$ y al menos de 13 elementos minerales mas. Seis de estos macroelementos $(\mathrm{N}, \mathrm{K}, \mathrm{Ca}$, $\mathrm{Mg}, \mathrm{P}$ y S) normalmente ocurren en las plantas en concentraciones mayores a $1000 \mathrm{mg} \mathrm{kg}^{-1}$. El resto de los elementos $(\mathrm{B}, \mathrm{Cl}$, $\mathrm{Cu}, \mathrm{Fe}, \mathrm{Mn}, \mathrm{Mo}, \mathrm{y} \mathrm{Zn}$ ) normalmente se encuentran en las plantas en concentraciones menores a $50 \mathrm{mg} \mathrm{kg}^{-1}$. Cantidades traza de otros elementos (por ejemplo, $\mathrm{Co}, \mathrm{Na}, \mathrm{Ni}$ y $\mathrm{Si}$ ) pueden ser benéficas para las plantas. En algunos zacates forrajeros las concentraciones de silicio pueden variar hasta $50,000 \mathrm{mg} \mathrm{kg}^{-1}$. Los elementos minerales requeridos por los animales incluyen los macroelementos $\mathrm{Ca}, \mathrm{Cl}, \mathrm{K}, \mathrm{Mg}, \mathrm{N}$, Na, P y S, los elementos traza o microelementos Co, Cu, Fe, I, Mn, Mo, Se y $\mathrm{Zn}$ y los elementos ultra-traza $\mathrm{Cr}$, Li y Ni. Cuando las concentraciones de estos elementos en los forrajes alcanzan proporciones altas su biodisponibilidad puede estar en peligro. Las interacciones de $\mathrm{K}$ x $\mathrm{Mg}$ x Ca, Ca $\times \mathrm{P}$, Se x S, y $\mathrm{Cu} \times \mathrm{Mo} \times \mathrm{S}$ se mencionan brevemente aquí porque en la literatura seran encontrados mas detalles. La información publicada disponible sobre $\mathrm{Si}$ es limitada por lo que nosotros damos mas detalle de ello. El silicio provee un soporte físico a las plantas y puede reducir la susceptibilidad a las plagas. Sin embargo, el Si puede tener efectos negativos en la digestibilidad y contribuir a formar cálculos urinarios en los animales.

and subsequent animal health problems. Silicon will be discussed in more detail since current coverage is sparse.

\section{Silicon}

Silicon receives major emphasis in this review because its role in forage and animal nutrition has not been greatly investigated. Silicon uptake, and subsequent deposition on leaf cell-wall, and especially on the leaf perimeter provides physical support to plants. Silicon deposits also reduce susceptibility to insect and fungal attack and may also reduce animal preference or palatability for certain plants (Jones and Handrek 1967, Shewmaker et al. 1989). There is unpublished work (Mayland, unpublished) suggesting a negative relationship between forage $\mathrm{Si}$ and digestibility of forage. In preliminary, unverified experimentation he found that in vitro dry matter digestibility of forage grasses was decreased 4 units for each unit of Si present in the forage. Shewmaker et al. (1989) suggest the following as possible roles of $\mathrm{Si}$ on digestibility. Once eaten, $\mathrm{Si}$ may reduce digestibility of forage by 1 ) acting as a varnish on the plant cell wall and reduc- 
Table 1. Nutrient element concentrations normally found in cool-season grasses and legumes and their requirement by sheep and cattle.

\begin{tabular}{|c|c|c|c|c|}
\hline \multirow[b]{2}{*}{ Element } & \multicolumn{2}{|c|}{ Concentrations in Forages ${ }^{1}$} & \multicolumn{2}{|c|}{ Dietary requirements $^{2}$} \\
\hline & Grasses & Legumes & Sheep & Cattle \\
\hline & \multicolumn{4}{|c|}{ 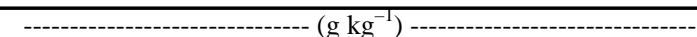 } \\
\hline Calcium, $\mathrm{Ca}$ & $3-6$ & $3-14$ & $3-4$ & $3-4$ \\
\hline Chlorine, $\mathrm{Cl}$ & $1-5$ & $1-5$ & 1 & 2 \\
\hline Magnesium, Mg & $1-3$ & $2-5$ & 1 & 2 \\
\hline Nitrogen, $\mathrm{N}$ & $10-40$ & $10-50$ & $10-15$ & $10-5$ \\
\hline Phosphorus, $\mathrm{P}$ & $2-4$ & $3-5$ & 2 & 2 \\
\hline Potassium, K & $10-30$ & $20-40$ & 3 & 8 \\
\hline Silicon, $\mathrm{Si}^{3}$ & $10-40$ & $0.5-1.5$ & \multicolumn{2}{|c|}{ requirement not established } \\
\hline Sodium, $\mathrm{Na}^{3}$ & $0.1-3.0$ & $0.1-2$ & 1 & 2 \\
\hline Sulfur, $\mathrm{S}$ & $1-4$ & $2-5$ & $1-2$ & $1-2$ \\
\hline & \multicolumn{4}{|c|}{ 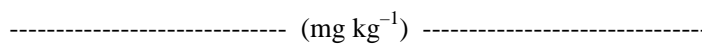 } \\
\hline Boron, B & $3-40$ & $30-80$ & \multicolumn{2}{|c|}{ requirement not established } \\
\hline Copper, $\mathrm{Cu}$ & $3-15$ & $3-30$ & $5-6$ & $7-10$ \\
\hline Fluorine, $\mathrm{F}^{3}$ & $2-20$ & $2-20$ & $1-2$ & $1-2$ \\
\hline Iron, $\mathrm{Fe}$ & $50-250$ & $50-250$ & 40 & 40 \\
\hline Manganese, Mn & $20-100$ & $20-200$ & 25 & 25 \\
\hline Molybdenum, Mo & $1-5$ & $1-10$ & $<0.1$ & $<0.1$ \\
\hline Zinc, $\mathrm{Zn}$ & $10-50$ & $15-70$ & $25-40$ & $25-40$ \\
\hline & \multicolumn{4}{|c|}{ 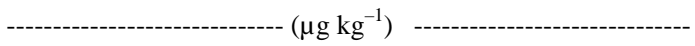 } \\
\hline Cobalt, $\mathrm{Co}^{3}$ & $50-300$ & $200-300$ & 100 & 60 \\
\hline Chromium, $\mathrm{Cr}^{3}$ & $200-1000$ & $200-1000$ & Trace & Trace \\
\hline Iodine, $\mathrm{I}^{3}$ & $40-800$ & $40-800$ & 500 & 500 \\
\hline Nickel, Ni & $200-1000$ & $200-1000$ & $60-70$ & $60-70$ \\
\hline Selenium, $\mathrm{Se}^{3}$ & $50-200$ & $50-200$ & $30-200$ & $40-300$ \\
\hline
\end{tabular}

${ }^{1}$ Herbage data are generalized from Fageria et al. (1991), Gough et al. (1979), Jones and Thomas (1987), Marschner (1986), Mayland (unpublished), Mays (1974), and Reid and Jung (1970)

${ }^{2}$ Animal data are generalized from Grace (1994), Grace and Clark (1991), Jones and Thomas (1987), NRC (1980). F, while not required by animals is beneficial to bones and teeth. Dietary requirements are for growing sheep and lactating cattle. Requirements may be different for other animal classes.

${ }^{3}$ Required by animals but not grasses or legumes.

ing accessibility to rumen microflora, 2) complexing trace elements like $\mathrm{Zn}$ and reducing their availability to rumen microflora, or 3) complexing enzymes that are integrally involved in rumen metabolism.

Silicon $(\mathrm{Si})$ is absorbed as monosilicic acid $\left[\mathrm{Si}(\mathrm{OH})_{4}\right]$ by plant roots, transported throughout the plant, and deposited primarily in epidermal cells, stoma and trichomes of leaves (Jarvis 1987). Some of this $\mathrm{Si}$ remains in soluble forms. Most $\mathrm{Si}$, however, is incorporated into or onto the cell wall structure or precipitated with other elements to form amorphous crystalline deposits called phytolyths (Blackman and Bailey 1971, Moore 1984). [The structure, shape, and color of plant phytolyths differ among grass genera and may be used for classification purposes in archeological sites.] Silicon uptake is largely passive, i.e., taken up with the transpiration stream, however, recent evidence has demonstrated that some energy mediated uptake of $\mathrm{Si}$ occurs in grasses (Jarvis 1987, Mayland et al. 1991).

The incorporation of $\mathrm{Si}$ into scabrous tissue is perceived as a defense mechanism against some insects (Moore 1984) and possibly against grazing by large herbivores (McNaughton et al. 1985). Silicon taken up by forage plants may also reduce rumen microbial accessibility to cell wall structure (Smith and Nelson 1975, Harbers et al. 1981), thereby reducing apparent digestibility of herbage (Van Soest and Jones 1968). Mika (1986) reported that a water-soluble form of Si inhibits activity of cellulases and other digestive enzymes, whereas the insoluble form is chemically inert. Thus, exogenous Si from ingested soil or dust adhering to herbage probably has little direct effect on digestibility.

Silicon, in addition to affecting forage quality, is implicated in animal health (Jones and Handreck 1967). In some early research, urolithiasis in steers was related $\left(r^{2}=0.56\right)$ to $\mathrm{Si}$ concentrations in Montana forage grasses (Parker 1957). However, Bailey (1976) later reported that frequency of urinary calculi encountered in Alberta cattle was inversely related to urine volume and water intake. This cause and effect relationship has not been resolved. Ingestion of certain $\mathrm{Si}$ minerals may increase the rate of tooth wear, thus reducing the effective lifetime of grazing animals (see also Soil Ingestion).

Shewmaker et al. (1989) determined the $\mathrm{Si}$ concentration in 31 accessions of C-3 grasses and the relationship of $\mathrm{Si}$ concentration to sheep preference. Silicon concentrations in leaves increase with advanc- ing phenological maturity and are greatest in leaves, intermediate in inflorescences, and least in stems. Awns contain high concentrations of Si. Silicon concentrations in leaves of Agropyron, Pseudoroegneria, and Thinopyrum increase at nearly twice the rate of those in Critesion, Hordeum, Leymus and Psathyrostachys (Fig. 1). Elymus leaves contain higher concentrations of $\mathrm{Si}$ at the vegetative stage than other groups, but the accumulation rate is intermediate.

Silicon is much more soluble in NDF than ADF extractions (Shewmaker, et al.1989). They found that in vegetative grass, about $32 \%$ of total leaf Si remains in the NDF residue. However, about $76 \%$ remains in the ADF residue. Some of the $\mathrm{Si}$ is insoluble in both extracts. These insoluble portions of $\mathrm{Si}$ increase with aging. Preference relates to estimated dry matter digestibility at boot and anthesis, but is not related to fiber or $\mathrm{Si}$ measurements.

Leaf $\mathrm{Si}$ concentration ranges from $7 \mathrm{~g}$ $\mathrm{kg}^{-1}$ in Hordeum to $47 \mathrm{~g} \mathrm{~kg}^{-1}$ in bluebunch wheatgrass (Pseudorogneria spicata $=$ Agropyrum spicatum [Pursh] Scribn. \& Smith). Indian ricegrass (Oryzopsis hymenoides (Roemer \& J.A. Schultes) ex Piper) contains $25 \mathrm{~g} \mathrm{Si} \mathrm{kg}^{-1}$ in leaves at the anthesis stage. Medusahead (Elymus caput-medusae L.) is very unpalatable and contains up to $113 \mathrm{~g} \mathrm{Si} \mathrm{kg}^{-1}$, whereas cheatgrass (Bromus tectorum L.) contains $44 \mathrm{~g} \mathrm{Si} \mathrm{kg}^{-1}$ (Bovey et al. 1961).

Silicon accumulation in 3 groups of grasses as a function of growth stage is shown in Figure.1. The wheatgrasses (group 1) generally reach physiological maturity quicker than wildryes (with the exception of Russian wildrye) and wild barleys (group 2). Group 1 plants tend to have fewer leaves, which on average may be chronologically older than leaves of group 2 plants. These older leaves of group 1 plants may have higher concentrations of Si because passively-transported $\mathrm{Si}$, taken up as a soluble component in the transpiration stream, accumulates for a longer time in leaves or because of differences in active transport (requiring energy) of Si from roots to leaves.

\section{Silicon in tall fescue and its relation to cattle preference.}

In our studies of cattle preferences among tall fescue cultivars, preference scores were not related to soluble or insoluble $\mathrm{Si}$ in $\mathrm{ADF}$ and NDF residue, nor to total $\mathrm{Si}$ at any phenological stage (Mayland, unpublished). Thus, cattle preference for these grasses is a function of factors other than Si components. There is 


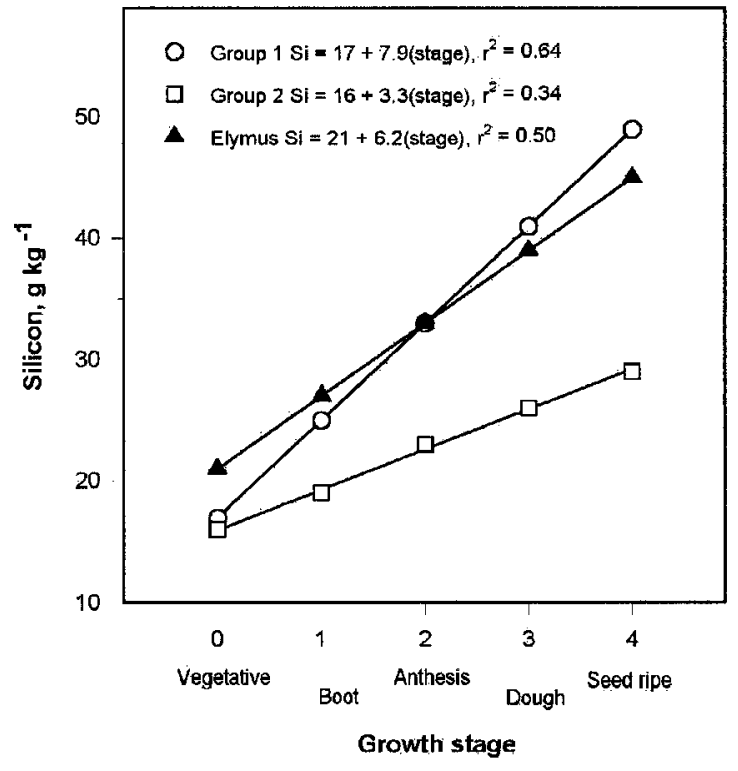

Fig. 1. Leaf silicon ( $\mathrm{Si}$ ) accumulation in $\mathrm{C}-3$ grasses as predicted by growth stage. Group 1 genera include Thinopyrum, Agropyron, and Pseudoroegneria, the wheatgrasses. Group 2 genera include Critesion, Hordeum, Psathyrostachys, and Leymus, wild-barley and wildrye. Data are adapted from Shewmaker et al. 1989.

evidence that $\mathrm{Si}$ concentration is higher in grazed plants than ungrazed plants on the Serengeti (McNaughton and Tarrants 1983) and in western wheatgrass (Pascopyrum smithii $=$ Agropyrum smithii [Rydb.] A. Love) on the northern plains (Brizuela et al. 1986). Brizuela also reports that hand-defoliated little bluestem (Schizachyrium scoparium [Michx.] Nash) contains lower Si concentrations than nondefoliated plants. The different Si concentrations may be a result of grazing-induced ecotypic differentiation (Detling and Painter 1983). The theory that Si is a short-term defense against large herbivores is clouded by the interaction with increased nutritional value of regrowth forage over initial forage.

\section{Magnesium x Potassium $x$ Calcium}

Hypomagnesemic grass tetany is probably the most important metabolic problem in ruminants caused by mineral imbalances (Mayland 1988). It is characterized by low blood plasma $\mathrm{Mg}$ concentrations $\left(<0.4 \mathrm{mmol} \mathrm{liter}^{-1}\right)$ and most assuredly by low urinary $\mathrm{Mg}$ concentrations (< 0.8 mmol liter $\left.{ }^{-1}\right)$. Although $2 \mathrm{~g} \mathrm{Mg} \mathrm{kg}^{-1} \mathrm{DM}$ is adequate to meet $\mathrm{Mg}$ requirements in most situations, cows and ewes near parturition and continuing into lactation, may need extra Mg (10 to $30 \mathrm{~g} \mathrm{Mg} \mathrm{cow-d^{-1 }}{ }^{-1}, 2$ to 3 $\left.\mathrm{g} \mathrm{Mg} \mathrm{ewe-day}^{-1}\right)$.
Magnesium absorption by both plants and ruminants is negatively affected by $K$. That interaction is the basis for the $\mathrm{K} /(\mathrm{Mg}+\mathrm{Ca})$ ratio in forages that provides a risk index. Calcium may counter some of the effects of $\mathrm{K}$ on $\mathrm{Mg}$ absorption. The risk of grass tetany increases exponentially when the herbage $\mathrm{K} /(\mathrm{Ca}+\mathrm{Mg})$ increases above 2.2 (expressed as moles of charge basis). Other factors that reduce $\mathrm{Mg}$ availability to ruminants include high concentrations of $\mathrm{N}$ and low concentrations of total soluble carbohydrate. Prudent use of $\mathrm{N}$ and $\mathrm{K}$ fertilizers is warranted to minimize risk of grass tetany (Mayland and Wilkinson 1989, Mayland et al. 1990). Aluminum in acid soil solutions may also reduce $\mathrm{Ca}$ and $\mathrm{Mg}$ uptake by cool season grasses and increase susceptibility to grass tetany (Rengel and Robinson 1989). Restoring available soil $\mathrm{P}$ to concentrations adequate for good plant growth has also elevated $\mathrm{Mg}$ and $\mathrm{Ca}$ concentrations in grass leaves (Reinbott and Blevins 1994).

Severity of economic livestock losses can be reduced by delaying early spring use of grass pastures, grazing with stocker and dry cows, and supplementing animals with soluble $\mathrm{Mg}$. The Mg may be provided in drinking water, licks, salt, or perhaps as a dust on the forage. On acid soils; liming with $\mathrm{Ca}-\mathrm{Mg}$ limestone (dolomite) rather than calcium limestone (calcite) would increase $\mathrm{Mg}$ availability to plants and likely to grazing animals. The method chosen will be greatly dependent on local conditions.
An alternative to fertilization or direct supplementation is to increase $\mathrm{Mg}$ in forage through plant breeding (Sleper et al. 1989). Progress has been made with Italian ryegrass (Lolium multiflorum Lam.) ( Moseley and Baker 1991, Moseley and Griffiths 1984), perennial ryegrass (Lolium perenne L.) (Binnie et al. 1996), and tall fescue (Mayland and Sleper 1993, Crawford et al. 1998). The new cultivars have resulted in reduced values of $\mathrm{K} /(\mathrm{Mg}+\mathrm{Ca})$ in forage, increased levels of blood plasma $\mathrm{Mg}$ in animals, and in high risk situations these high magnesium cultivars have reduced the incidence of grass tetany death losses by grazing animals.

Potassium levels of $28 \mathrm{~g} \mathrm{~kg}^{-1} \mathrm{DM}$ in herbage will provide near maximum herbage yield of cool-season grasses. However, increases in solution $\mathrm{K}$ concentration reduce uptake of both $\mathrm{Ca}$ and $\mathrm{Mg}$ by plants, even at higher solution $\mathrm{K}$ levels resulting in less than maximum forage yield. Smith et al. (1985) reported that $\mathrm{Mg}$ concentrations level out at $1.9 \mathrm{~g} \mathrm{~kg}^{-1}$ when herbage contains $\geq 25 \mathrm{~g} \mathrm{~K} \mathrm{~kg}^{-1}$; whereas $\mathrm{Ca}$ concentration continues to decrease to a low of $6 \mathrm{~g} \mathrm{~kg}^{-1}$ as forage $\mathrm{K}$ increases to $65 \mathrm{~g}$ $\mathrm{K} \mathrm{kg}^{-1}$. High herbage $\mathrm{K}$ levels also depresses $\mathrm{Mg}$ and $\mathrm{Ca}$ absorption by ruminants.

On the other hand, $\mathrm{K}$ concentrations in dry-mature or winter grass (standing or harvested) may be inadequate for cattle requirements. This may occur because of weathering and leaching of $\mathrm{K}$ from the curing forage. Minimum critical levels for cattle are in the range of $5-10 \mathrm{~g} \mathrm{~kg}^{-1}$. During summer, $20 \mathrm{~g} \mathrm{~K} \mathrm{~kg}^{-1} \mathrm{DM}$ may be desired to reduce heat stress in cattle. Prudent applications of fertilizer $K$ are required to meet plant growth requirements, and not aggravate the risk of lowered $\mathrm{Mg}$ and Ca uptake by plants and absorption by animals.

\section{Calcium x Phosphorus}

Milk fever or parturient paresis, is characterized by low blood $\mathrm{Ca}(<1.0 \mathrm{mmol}$ liter $\left.{ }^{-1}\right)$. It occurs during late pregnancy and onset of lactation. This situation can occur even though herbage contains $4.4 \mathrm{~g} \mathrm{Ca} \mathrm{kg}^{-1}$ DM. Animals must be treated parenterally with $\mathrm{Ca}$ for several days. Calcium:phosphorus ratio of $2: 1$ (wt:wt) is ideal, but $8: 1$ has been tolerated. In extreme situations, cattle and sheep may be observed chewing on bones. This behavior may be indicative of a P deficiency. Animal nutritional guides generally discuss ratios of $\mathrm{Ca}: \mathrm{P}$ rather than absolute dietary concentrations. 


\section{Sulfur x Selenium}

A blind staggers, or more correctly, polioencephalomalacea may occur if ruminants ingest excess sulfate sulfur (James et al. 1994, Mayland 1995, O'Toole et al. 1996). This occurs when ruminant organisms reduce $\mathrm{SO}_{4}$ to the toxic $\mathrm{H}_{2} \mathrm{~S}$ form. Sulfate in drinking water should be considered suspect in these cases (Mayland 1995). Interactions of S x Se may occur when $S$ fertilization results in forage crop yield response. The reduced Se absorption by the plant may occur because of a direct competition of S reducing the uptake of $\mathrm{Se}$ or may occur by dilution of Se in the plant (Mayland and Robbins 1994, Wu and Huang 1991).

\section{Selenium}

Selenium is needed for animal health in low concentrations but is toxic at high. It may occur in high to toxic (to animals) levels in herbage grown on Cretaceous geological soils, especially in the Central Plains of North America. In other areas, herbage Se concentrations may be inadequate for animal requirements. Dietary $\mathrm{Se}$ requirements range from 0.03 to as much as $1.0 \mathrm{mg} \mathrm{Se} \mathrm{kg}{ }^{-1} \mathrm{DM}$. The amount is dependent upon the class of animal and levels of vitamin E, S, and other factors present in the diet. The effect of Se is complemented to some extent by that of vitamin E. High levels of dietary S will counter the availability of Se to ruminants. Whole blood Se concentrations should be greater than $250 \mathrm{nmol}$ liter $^{-1}$.

Selenium is the only mineral whose supplementation of food animals is regulated by the US Food and Drug Administration (FDA 1993). Effective 13 September 1993, the FDA permitted an increase of $0.1 \mathrm{mg} \mathrm{Se} \mathrm{kg}^{-1}$ (as sodium selenite or sodium selenate) in complete feeds for animals. The use of Se boluses is not permitted. Congress and U.S. President Clinton suspended the FDA action until 31 December 1995 (Gloyd 1994). Thus, during 1995, animal and fowl feeds could contain $0.3 \mathrm{mg} \mathrm{Se} \mathrm{kg}^{-1}$ and the osmotic Se bolus for cattle could be used as a source of Se. These on-again, off-again, changedagain regulations have not satisfactorily met Se nutrition needs of animals. The current status is that none of the regulations adequately consider the level nor bioavailability of Se in naturally occurring feedstuffs. Selenium deficiency causes white muscle disease, ill thrift, and reduced fertility, in animals. Alkali disease and acute toxicosis (selenosis) may occur when animals ingest excess $\mathrm{Se}\left(>5 \mathrm{mg} \mathrm{kg}^{-1}\right)$ (Mayland 1994).

\section{Copper x Molybdenum $\mathbf{x}$ Sulfur x Iron}

Copper deficiencies may occur in grazing animals (Baker and Ammerman 1995). Reduced bioavailability of $\mathrm{Cu}$ occurs in the presence of increased intake and bioavailability of Mo, S, and Fe. The formation of thiomolybdates in the gut, reduces absorption of $\mathrm{Cu}$ by animals (Baker and Ammerman 1995). Dietary $\mathrm{Cu}$ intake should be decreased in those areas where herbage Mo levels are extremely low. When Mo levels are high as they might be in some meadow soils, then $\mathrm{Cu}$ supplementation should be increased. Copper requirements for cattle are about twice those for sheep. Several incidences of $\mathrm{Cu}$ toxicity in grazing sheep have been reported on recently manured pastures. These are associated with swine or poultry manures from operations where $\mathrm{Cu}$ anthelmintics are used for control of intestinal parasites (McDowell 1992, Suttle and Price 1976). Copper bioavailability differs among some grasses as Stoszek et al. (1986) showed for cattle grazing tall fescue or quackgrass. Nutritionists should be alert to signs of $\mathrm{Cu}$ deficiency or toxicity in animals, because of the many opportunities for interaction that affect $\mathrm{Cu}$ bioavailability.

\section{Cobalt, Fluorine, Iodine}

The Co requirements for sheep are about twice those for cattle (Henry 1995). Lambs are most sensitive to Co deficiency. Fluorine in concentrations of 1 to $2 \mathrm{mg}$ $\mathrm{F} \mathrm{kg}^{-1}$, while not required by animals, is beneficial for high tooth and bone density. Concentrations of 4 to $8 \mathrm{mg} \mathrm{F} \mathrm{kg}^{-1}$ will cause brown staining of tooth enamel and concentrations greater than $8 \mathrm{mg} \mathrm{F} \mathrm{kg}^{-1}$ will reduce tooth and bone density and increase tendency for breakage. Drinking water is the primary source of F. Sprinkle irrigation of forages, using high $\mathrm{F}$ water, is another way in which animals may ingest excess F (Wallender and Keller 1984). High $\mathrm{F}$ is often associated with thermal water and with rock phosphates used for supplemental $\mathrm{P}$ in rations. The $\mathrm{F}$ intake may not be a problem for adult animals. However, for young growing stock intake of excess $\mathrm{F}$ will weaken tooth and bone formation and livestock men should con- sider growing these animals in other areas where $F$ intake is much less (Mayland, personal experience).

Animal performance can be good on pastures containing $0.3 \mathrm{mg} \mathrm{I} \mathrm{kg}{ }^{-1} \mathrm{DM}$, however, the northern half of the U.S. and Canada is generally I-deficient (McDowell 1992, Miller and Ammerman 1995). Salt $(\mathrm{NaCl})$ is a common carrier of supplemental I for both human and domestic livestock and will be identified as iodized salt (Miller and Ammerman 1995). Dietary intakes of 1 to $2 \mathrm{mg} \mathrm{I} \mathrm{kg}^{-1} \mathrm{DM}$ must be considered when animals are eating goitrogenic plants like turnips and other Brassica species (Miller and Ammerman 1995).

\section{Ultra-Trace Elements}

The elements $\mathrm{Al}, \mathrm{As}, \mathrm{Cr}, \mathrm{Ni}, \mathrm{V}, \mathrm{Sn}$ are presumed essential for ruminants although research data are not available. If required, the dietary concentrations must be extremely low. Using the definition of essentiality for plants; one might also add $\mathrm{Ba}, \mathrm{Br}, \mathrm{F}, \mathrm{Rb}$, and $\mathrm{Sr}$. We have measured $<0.5 \mathrm{mg} \mathrm{Cd} \mathrm{kg}{ }^{-1}$ $\mathrm{DM}$ and 0.5 to $6 \mathrm{mg} \mathrm{F} \mathrm{kg}^{-1} \mathrm{DM}$ in grass herbage. We are currently not aware of any factors that might affect the bioavailability of these ultra-trace elements. Several of these elements, if required by plants and animals, must be at such low concentrations in nutrient culture or in diet that it is difficult to conduct a sufficiently 'clean environment' to test their essentiality.

\section{Interaction with Immunological Requirements}

The mineral element requirement of animals is defined as the amount of bioavailable nutrient in the diet required for growth and reproduction and further that the element is the only component that can meet that animal's needs. There is increasing evidence (Mayland et al. 1987) suggesting that for some trace elements, a higher concentration of the element may be needed for maintaining the animal's immune system than is currently considered as required for good growth and performance. Experimental results, however, are mixed and possibly animal species dependent (Ward and Spears 1999). Further experimentation is required to substantiate the role of trace element requirements and the development of full immunological response levels. 


\section{Soil Contamination of Forage Soil Intake by Animals}

Mineral element concentrations of analyzed herbage samples may be significantly biased by the presence of dust or soil adhering to the material (exogenous components). Such contamination is reflected by plant sample $\mathrm{Fe}$ concentrations greater than $250 \mathrm{mg} \mathrm{kg}^{-1} \mathrm{DM}$ (Mayland and Sneva 1983). Laboratory personnel in the senior author's lab routinely use a level of 400 as a threshold indicator of possible soil contamination of plant samples. Soil contamination on herbage may elevate the intake of $\mathrm{Fe}, \mathrm{Mn}, \mathrm{Se}, \mathrm{Co}$, and other elements above the true elemental composition of the herbage. Direct soil ingestion by animals may also affect the intake of some mineral elements (Mayland et al. 1975, 1977, Sneva et al. 1983 ). This source of mineral elements may be important when studying trace element responses of free grazing livestock (Mayland et al. 1980). In some situations the eating of soil (a form of geophagia) is an attempt to provide a dietary buffer. In horses, it is often a behavioral response to boredom with the subsequent risk of developing an irritating and sometimes fatal case of sand collic.

Ingested soil can have another impact on animal health as is seen in the following case. Breeding cattle from one area of the Great Basin, contrasted to cattle from other areas, are routinely discounted when sold through the regional livestock auction barn. This discounting occurs because of a significantly greater loss or wearing of teeth. These animals may ingest more soil than others. A check of surface minerals from those grazing lands indicate a hardness (Moh scale) much greater than tooth enamel and thus minerals in the ingested soil serve as an abrasion to the enamel. Tooth enamel is apatite with a rating of 5, whereas talc is rated 1 and diamond is rated 10 . Soil minerals range several points above or below 5 .

\section{Urolithiasis}

Male sheep or cattle are more prone to kidney stones when the dietary $\mathrm{Ca}: \mathrm{P}$ is less than 2:1 or ingested $\mathrm{Si}$ is high and water intake is limited (Bailey 1976). Supplementing $\mathrm{Ca}$ will reduce the incidence of this problem only if the stones are analyzed as containing high concentrations of P. Providing adequate and quality drinking water will reduce the incidence of silicosis.

\section{Summary}

Discussions of mineral nutrition of forage plants and forbs must include the elemental needs of both plant and grazing animal. Grasses require 6 macronutrients $(\mathrm{N}, \mathrm{K}, \mathrm{Ca}, \mathrm{Mg}, \mathrm{P}$, and $\mathrm{S})$ in concentrations exceeding $1,000 \mathrm{mg} \mathrm{kg}^{-1}$. They also require 7 micronutrients $(\mathrm{B}, \mathrm{Cl}, \mathrm{Cu}, \mathrm{Fe}$, $\mathrm{Mn}, \mathrm{Mo}$, and $\mathrm{Zn}$ ) in concentrations ranging from 0.1 to $50 \mathrm{mg} \mathrm{kg}^{-1}$. Some ultratrace elements like $\mathrm{Ni}, \mathrm{Co}, \mathrm{Si}$, and $\mathrm{Na}$ may also be needed by cool-season grasses.

Grazing animals require 8 macronutrients. This list includes the same 6 needed by plants plus $\mathrm{Na}$ and $\mathrm{Cl}$. Animals require some of the same micronutrients as plants $(\mathrm{Cu}, \mathrm{Fe}, \mathrm{Mn}, \mathrm{Mo}$, and $\mathrm{Zn}$ ) plus $\mathrm{Co}$, I and Se. Animals may also require ultratrace quantities of $\mathrm{Cr}, \mathrm{Li}$, and $\mathrm{Ni}$.

Grasses may exhibit macronutrient deficiencies but seldom suffer from micronutrient deficiencies. However, they may not provide sufficient macronutrients $(\mathrm{N}, \mathrm{Ca}$, $\mathrm{Mg}, \mathrm{P}$, and $\mathrm{S})$, micronutrients $(\mathrm{Cl}, \mathrm{Cu}$ or $\mathrm{Zn}$ ), or other elements (I, Na or $\mathrm{Se}$ ) and thus fail to meet the animal's nutritional needs. Paddocks of cool-season grasses are often fertilized with $\mathrm{N}$ and $\mathrm{K}$. If $\mathrm{N}$-fixing legumes are present then $\mathrm{P}$ may be applied to these paddocks and $\mathrm{N}$ fertilization is omitted. Grazing animals are generally supplemented with $\mathrm{NaCl}$ and may also receive additional amounts of I, Se, $\mathrm{Zn}$, and Co trace mineral to supplement their forage diets. Ruminants may also receive supplementary $\mathrm{Mg}$ where there is considerable risk of grass tetany.

Often grass and forb diets will contain nutrient levels considered adequate, but the bioavailability of some minerals may be reduced because of interactions like $\mathrm{K}$ x $\mathrm{Mg}, \mathrm{Mo} \times \mathrm{Cu}$ x S, and $\mathrm{S}$ x Se. Split applications of $\mathrm{K}$ fertilizer will minimize the impact of high $\mathrm{K}$ levels on $\mathrm{Mg}$ availability to the plant and subsequent animal.

Forages in some geographic areas contain sufficient mineral nutrients to maintain herbage growth, but there may be an insufficient amount of $\mathrm{Cu}, \mathrm{Mg}$, Se (not needed by plants), or $\mathrm{Zn}$ to meet animal requirements. For example, tall fescue is well adapted to many areas of the U.S. Soils in these areas contain little plantavailable Se and plants growing on them may not take up sufficient Se to meet animal requirements (McQuinn et al.1991). Management programs that allow for direct or indirect supplementation of these nutrients to the animals should be considered.

Knowledge of mineral element requirements of forages plants and grazing animals is essential to understand the complex interactions that one element may have on another.

\section{References}

Bailey, C.B. 1976. Effects of ammonium chloride on formation of siliceous urinary calculi in calves. Can. J. Anim. Sci. 56:359-360.

Baker, D.H. and C.B. Ammerman. 1995. Copper bioavailability. 127-157. In: C.B. Ammerman, D.H. Baker, and A.J. Lewis. Bioavailability of nutrients for animals. Academic Press., N.Y.

Binnie, R.C., D.T. Hohnston, and D.M.B. Chestnutt. 1996. The effect of a high-magnesium perennial ryegrass variety on the magnesium status of sheep. Grass Forage Sci. 51:456-463.

Blackman, E. and C.B. Bailey. 1971. Dissolution of silica from dried grass in nylon bags placed in the rumen of a cow. Can. J. Anim. Sci. 51:327-332.

Bovey, R.W., D. Le Tourneua, and L.C. Erikson. 1961. The chemical composition of medusahead and downy brome. Weeds 9:307-311.

Brizuela, M.A., J.K. Detling, and M.S. Cid. 1986. Silicon concentration of grasses growing in sites with different grazing histories. Ecol. 67:1098-1101.

Crawford, R.J., Jr., M.D. Massie, D.A. Sleper, and H.F. Mayland. 1998. Use of an experimental high-magnesium tall fescue to reduce grass tetany in cattle. J. Prod. Agr., 11:491-496

Detling, J.K. and E.L. Painter. 1983. Defoliation responses of western wheatgrass populations with diverse histories of prairie dog grazing. Oecologia (Berlin) 57:65-71.

Fageria, N.K., V.C. Baligar, and C.A. Jones. 1991. Growth and mineral nutrition of field crops. Marcel Dekker, N.Y.

Food and Drug Administration (FDA). 1993. Food additives permitted in feed and drinking water of animals; Selenium. Federal Register (13 Sept. 1993) 56 (175): 47962-47973.

Gloyd, J.S. 1994. Stay of selenium amendments lifted. J. Amer. Vet. Med. Assoc. 205:1639.

Gough, L.P., H.T. Shacklette, and A.A. Case. 1979. Element concentrations toxic to plants, animals, and man. U.S. Geol. Surv. Bull. 1466.

Grace, N.D. 1994. Managing trace element deficiencies. AgResearch, New Zealand Pastoral Agr. Res. Inst., Publ. Palmerston North, N.Z.

Grace, N.D. and R.G. Clark. 1991. Trace element requirements, diagnosis and prevention of deficiencies in sheep and cattle. p. 321-345. In: T. Tsuda, Y. Sasaki, and R. Kawashima. (ed.). Physiological aspects of digestion and metabolism in ruminants. Academic Press, San Diego, Calif.

Harbers, L.H., D.J. Raiten, and G.M. Paulsen. 1981. The role of plant epidermal silica as a structural inhibitor of rumen microbial digestion in steers. Nutr. Rep. Int. 24:1057-1066

Harris, K.B., V.M. Thomas, M.K. Peterson, S.D. Kachman, and M.J. McInerney. 1989. Influence of minerals on rate of digestion and percentage degradable in vitro neutral detergent fiber. Nutr. Rep. Int. 40:219-226.

Henry, P. 1995. Cobalt bioavailability. p. 1191126. In: C.B. Ammerman, D.H. Baker, and A.J. Lewis. Bioavailability of nutrients for animals. Academic Press. N.Y.

James, L.F., W.F. Hartley, K.E. Panter, B.L. Stegelmeier, D. Gould, and H.F. Mayland. 1994. Selenium poisoning in cattle. P. 416-420. 
In: S.M. Colegate and P.R. Dorling (eds.) $\mathrm{CAB}$ International Wallingford, U.K.

Jarvis, S.C. 1987. The uptake and transport of silicon by perennial ryegrass and wheat. Plant and Soil 97:429-437.

Jones, L.H.P. and K.A. Handrek. 1967. Silica in soil, plants and animals. Adv. Agron. 19:107-149.

Jones, D.I.H., and T.A. Thomas. 1987. Minerals in pastures and supplements. p. 145-153. In R.W. Snaydon (ed.) Managed grasslands. Analytical studies (Ecosystems of the world 17B). Elsevier Sci. Publ., Amsterdam.

Kabata-Pendias, A. and H. Pendias. 1992. Trace elements in soils and plants. 2nd ed. CRC Press. Boca Raton, Fla.

Marschner, H. 1986. Mineral nutrition of higher plants. Academic Press. San Diego, Calif.

Mayland, H.F. 1988. Grass tetany. p. 511-523 and 530-531. In: D.C.Church (ed.) The ruminant animal: Its physiology and nutrition. Prentice-Hall. Englewood Cliffs, NJ, Reissued by Waveland Press, Inc. Prospect Heights, Ill.

Mayland, H.F. 1994. Selenium in plant and animal nutrition. P. 29-45. In: W.T Frankenberger, Jr. and S. Benson. Selenium in the Environment. Marcel Dekker, Inc. N.Y.

Mayland, H.F. 1995. Absorption of excess selenium and sulfur by plants and animals. P. 362-371. Proc. National meeting of the Amer. Soc. for Surface Mining and Reclam., Gillette, Wyoming, June 5-8, 1995.

Mayland, H.F. and P.R. Cheeke. 1995. Forage-induced animal disorders. In: R.F Barnes, D.A. Miller, and C.J. Nelson (ed.) Forages. The science of grassland agriculture. 5th ed. Iowa State University Press, Ames, Iowa.

Mayland, H. F. and C.W. Robbins. 1994 Sulfate uptake by salinity-tolerant plant species Commun. Soil Sci. Plant Anal. 25:2523-2541.

Mayland, H.F. and D.A. Sleper. 1993. Developing a tall fescue for reduced gras tetany risk. p. 1095-1096. In: J. Hogson (ed.) Proc. $17^{\text {th }}$ Int. Grassl. Congr., Palmerston North, New Zealand. 8-21 Feb. Dunmore Press, Palmerston North.

Mayland, H.F. and F.A. Sneva. 1983. Effect of soil contamination on the mineral composition of forage fertilized with nitrogen. J. Range Manage. 36:286-288.

Mayland, H.F. and S.R. Wilkinson. 1989. Soil factors affecting magnesium availability in plant-animal systems: a review. J. Anim. Sci. 67:3437-3444.

Mayland, H.F., T.R. Kramer, and W.T Johnson. 1987. Trace elements in the nutrition and immunological response of grazing livestock. pp. 101-113. In: Judkins, M. B., Clanton, D. C., Petersen, M. K., and Wallace, J. D. (eds.) Proc. Grazing Livestock Nutrition Conference. 23-24 July, Jackson, Wyo.

Mayland, H. F., R.C. Rosenau, and A.R. Florence. 1980. Grazing cow and calf responses to zinc supplementation. J. Anim. Sci 51:966-974.

Mayland, H.F., G.E. Shewmaker, and R.C. Bull. 1977. Soil ingestion by cattle grazing crested wheatgrass. J. Range Manage. 30:264-265.

Mayland, H.F., J.L. Wright, and R.E. Sojka. 1991. Silicon accumulation and water uptake by wheat. Plant and Soil 137:191-199
Mayland, H.F., L.W. Greene, D.L. Robinson, and S.R. Wilkinson. 1990. Grass Tetany: A review of $\mathrm{Mg}$ in the soil-plant-animal continuum. Proc. 25 ${ }^{\text {th }}$ annual Pacific Northwest Anim. Nutr. Conf., 6-8 Nov. 1990, Vancouver, British Columbia.

Mayland, H.F., A.R. Florence, R.C. Rosenau, V.A. Lazar, and H.A. Turner. 1975. Soil ingestion by cattle on semiarid range as reflected by titanium analysis of feces. J. Range Manage. 28:448-452.

Mays, D.A. (Ed.) 1974. Forage fertilization. Amer. Soc. Agron. Madison, Wisc.

McDowell, L.R. 1992. Minerals in animal and human nutrition. P. 203. Academic Press, Inc., N.Y.

McNaughton, S.J. and J.L. Tarrants. 1983. Grass leaf silicification: natural selection for an inducible defense against herbivores. Proc. Nat. Acad. of Sci. (USA) 80:790-791.

McNaughton, S.J., J.L. Tarrants, M.M. Mcnaughton, and R.H. Davis. 1985. Silica as a defense against herbivore and a growth promoter in African grasses. Ecol. 66:528-535.

McQuinn, S.D., D.A. Sleper, H.F. Mayland, and G.F. Karuse. 1991. Genetic variation for selenium content in tall fescue. Crop Sci. $31: 617-620$

Mika, V. 1986. The effect of the water-soluble form of silicon in fodder crops on their digestibility. Sci. Agr. Bohemoslovaca 18:185-190.

Miller, E.R., and C.B. Ammerman. 1995. Iodine bioavailability. p. $157-167$. In: C.B. Ammerman, D.H. Baker, and A.J. Lewis. Bioavailability of nutrients for animals. Academic Press. N.Y.

Moore, D. 1984. The role of silica in protecting Italian ryegrass (Lolium multiflorum) from attack by dipterous stem-boring larvae (Oscinella frit and other related species). Ann. Appl. Biol. 104:161-166.

Moseley, G. and D.H. Baker. 1991. The efficacy of a high magnesium grass cultivar in controlling hypomagnesemia in grazing animals. Grass Forage Sci. 46:375-380

Moseley, G. and D.W. Griffiths. 1984. The mineral metabolism of sheep fed high and low magnesium selections of Italian ryegrass. Grass and Forage Sci. 39:195-199.

National Research Council (NRC). 1980. Mineral tolerance of domestic animals. National Academy Press. Washington, D.C.

Nicholas, D.J.D. and A.R. Egan. 1975. Trace elements in soil-plant-animal systems. Academic Press, Inc., N.Y.

O'Toole, D., M. Raisbeck, J.C. Case, and T.D. Whitson. 1996. Selenium-induced "Blind Staggers" and related myths. A commentary on the extent of historical livestock losses attributed to selenosis on Western US rangelands. Vet. Pathol. 33:104-116.

Parker, K.G. 1957. "Water-belly" (urolithiasis) in range steers in relation to some characteristics of rangeland. J. Range Manage. 10:105-111.

Reid, R.L. and D.J. Horvath. 1980. Soil chemistry and mineral problems in farm livestock. A review. Anim. Feed Sci. Tech. 5:95-167.

Reid, R.L. and G.A. Jung. 1970. Mineral composition of forages. West Virginia Agr. Exp. Sta. Bull. 589T
Reinbott, T.M. and D.G. Blevins. 1994. Phosphorus and temperature effects on Magnesium, calcium, and potassium, in wheat and tall fescue leaves. Agron. J. 86:523-429.

Rengel, Z. and D.L. Robinson. 1989. Aluminum effects on growth and macronutrient uptake by annual ryegrass. Agron. J. 81:208-215.

Shewmaker, G.E., H.F. Mayland, R.C. Rosenau, and K.H. Asay. 1989. Silicon in C-3 grasses: Effects on forage quality and sheep preference. J. Range Manage. 42:122-127.

Sleper, D.A., K.P. Vogel, K.H. Asay, and H.F. Mayland. 1989. Using plant breeding and genetics to overcome the incidence of grass tetany. J. Anim. Sci. 67:3456-3462.

Smith, G.S. and A.B. Nelson. 1975. Effects of sodium silicate added to rumen cultures on forage digestion, with interactions of glucose, urea and minerals. J. Anim. Sci. 41:891-899.

Smith, G.S., I.S. Cornforth, and H.V. Henderson. 1985. Critical leaf concentrations for deficiencies of nitrogen, potassium, phosphorus, sulphur, and magnesium in perennial ryegrass. New Phytol. 101:393-409.

Sneva, F.A., H.F. Mayland, and M. Vavra. 1983. Soil ingestion by ungulates grazing a sagebrush-bunchgrass range in eastern Oregon: Source of dietary minerals. Oregon Agr. Expt. Sta. Special Report \#682. p 35-39.

Spears, J.W. 1994. Minerals in forages. 281-317. In: G.C. Fahey (ed.). Forage quality, evaluation, and utilization. ASA, CSSA, SSSA. Madison, Wisc.

Stoszek, M.J., P.G. Mika, J.E. Oldfield and P.H. Weswig. 1986. Influence of copper supplementation on blood and liver copper in cattle fed tall fescue or quackgrass. J. Anim. Sci. 62:263-271.

Suttle, N.F. and J. Price. 1976. The potential toxicity of copper-rich animal excreta to sheep. Anim. Prod. 23:233-241.

Van Soest, P.J. and L.H.P. Jones. 1968. Effect of silica in forages upon digestibility. J. Dairy Sci. 51:1644-1648

Wallender, W.W. and J. Keller. 1984. Foliar fluoride accumulation under sprinkle irrigation. Trans. ASAE. 27:449-455.

Ward, J.D. and J.W. Spears. 1999. The effects of low-copper diets with or without supplemental molybdenum on specific immune responses of stressed cattle. J. Anim. Sci. 77:230-237.

Wu, L. and Z.Z Huang. 1991. Chloride and sulfate salinity effects on selenium accumulation by tall fescue. Crop Sci. 31:114-118. 